\title{
Estudos epidemiológicos entre grupos indígenas de Rondônia. IV. Inquéri- to sorológico para rotavírus entre os Suruí e Karitiána
}

\author{
Epidemiological studies among Amerindians of Rondônia. IV. Note of serologi- \\ cal survey for rotavirus antibodies among Suruí and Karitiána
}

\author{
Ricardo V. Santos ${ }^{\star}$, Alexandre C. Linhares ${ }^{\star}$, Carlos E.A. Coimbra Jr. ${ }^{\star}$
}

\begin{abstract}
SANTOS R.V. et al. Estudos epidemiológicos entre grupos indígenas de Rondônia. IV. Inquérito sorológico para rotavírus entre os Suruí e Karitiána. Rev. Saúde públ., S. Paulo, 25: $230-2,1991$. São apresentados os dados de um inquérito soro epidemiológico para anticorpos anti-rotavírus conduzido entre os Suruí e Karitiána, dois grupos indigenas de Rondônia, Brasil. Os resultados indicam que as porcentagens de soropositividade são elevadas $(67,8 \%$ para os Suruí e $77,4 \%$ para os Karitiána, através da técnica ELISA, e 45,5\% para os Suruí e 56,7\% para os Karitiána, através de imunofluorescência indireta). Testes de qui-quadrado indicam não haver associação estatisticamente significante entre grupo e positividade sorológica. São discutidos os resultados à luz de outros estudos conduzidos com grupos indígenas brasileiros.
\end{abstract}

Descritores: Rotavírus. Índios sul-americanos.

\section{Introdução}

É bem conhecida a relevância das infecções diarréicas no quadro de morbi-mortalidade, principalmente de crianças em populações de baixo nível sócioeconômico e carentes de infra-estrutura sanitária básica. No que tange à etiologia dessas infecções, destacam-se os rotavírus por sua associação em uma alta percentagem da casuística 1.11 .

Apesar da reconhecida importância sanitária das diarréias entre populações indígenas brasileiras, são poucos os estudos que investigaram a ocorrência de microrganismos enteropatogênicos entre tais populações $4,5,6,7,9,10$. Alguns deles incluíram sorologia para rotavírus com vistas a esclarecer o papel desse agente etiológico na epidemiologia de gastroenterites entre grupos indígenas 6,7 .

O objetivo do presente trabalho é apresentar os resultados de um inquérito sorológico para anticorpos anti-rotavírus realizado entre dois grupos indígenas de Rondônia - Suruí e Karitiána.

\footnotetext{
* Núcleo de Doenças Endêmicas Samuel Pessoa. Escola Nacional da Saúde Pública. Rio de Janeiro, RJ, Brasil.

** Instituto Evandro Chagas. Fundação Nacional da Saúde, PA, Belém, Brasil.

Separatas/Reprints: R.V. Santos - Rua Leopoldo Bulhões, 1480, Manguinhos, 21041, Rio de Janeiro, RJ - Brasil
}

\section{Material e Método}

As amostras de sangue foram coletadas em dezembro de 1982, entre os Suruí (59 amostras), e julho de 1983, entre os Karitiána (31 amostras), representando $19,7 \%$ da população Suruí e 36,5\% da Karitiána. Ambos os grupos vivem em reservas indigenas localizadas no Estado de Rondônia. Indivíduos de ambos os sexos e diversas faixas etárias compõem a amostra.

Os Suruí localizam-se na Área Indigena Sete de Setembro, às margens do igarapé de mesmo nome, afluente do Rio Branco (Parque Indígena Aripuanã). Na época em que a pesquisa foi realizada a população era de aproximadamente 300 indivíduos, distribuída em três aldeamentos. O material reportado no presente trabalho foi coletado na aldeia denominada Sete de Setembro.

Os Karitiána vivem no Posto Indigena Karitiána, situado às margens do igarapé Sapoti, afluente do Rio das Garças. A população do grupo era de aproximadamente 85 indivíduos em 1983.

As condições sanitárias de ambos os grupos caracterizavam-se por sua precariedade. Por ocasião da pesquisa, não havia latrinas ou água encanada nas casas. Os locais preferidos para defecção eram aqueles situados no peridomicílio das aldeias. Cursos de água de pequena dimensão eram utilizados como fonte de água para às mais diversas atividades. A disponibilidade 
de água tornava-se crítica particularmente no período de estiagem (julho-agosto), quando o nível da água baixa muito, concentrando os detritos orgânicos.

O sangue foi desorado no campo e as amostras congeladas a $-10^{\circ} \mathrm{C}$. A pesquisa de anticorpos para rotavírus foi realizada no Laboratório de Virologia do Instituto Evandro Chagas em 1983, utilizando-se dois procedimentos - imunofluorescência indireta (IF) e a técnica imunoenzimática (ELISA), como descrito em Linhares e $\mathrm{col}^{7}$. (1986).

\section{Resultados}

Os resultados dos testes ELISA e IF, de acordo com faixa etária, para os Suruí e Karitiána, estão sumarizados na Tabela.

Pela técnica ELISA, $67,8 \%$ do total da amostra Suruí e 77,4\% da Karitiána mostraramse positivos. Os resultados obtidos a partir da técnica IF indicam prevalências mais baixas para os dois grupos, respectivamente de $45,5 \%$ para os Suruí e $56,7 \%$ para os Karitiána (Tabela). Testes de qui-quadrado indicaram não haver associação estatisticamente significante ao nível de $5 \%$ entre as variáveis grupo e total de casos positivos segundo ELISA (X: $=0.916,1$ g. 1 ., $\mathrm{p}=0.34)$ ou IF (X: $=0.639,1 \mathrm{~g} .1 ., \mathrm{p}=0.42)$.

Os dados indicam que mais de $50 \%$ dos indivíduos da maioria das faixas etárias de ambos os grupos apresentam anticorpos antirotavírus, segundo as duas técnicas empregadas (Tabela). Como se observa, as percentagens são altas em todas as faixas etárias, sendo que as dos Karitiána tendem a ser mais elevadas que as dos Suruí. Infelizmente, devido ao reduzido tamanho da amostra, não foram empregados testes estatísticos de modo a detectar possíveis diferenças entre as diversas faixas-etárias.

Os resultados das sorologias obtidos pelas técnicas ELISA e IF apresentaram uma concordância de $61,5 \%$ para os Suruí e $66,7 \%$ para os Karitiána.

\section{Discussão}

Os resultados desse estudo estão de acordo com os de outros autores que apontam, em geral, elevadas prevalências de positividade para anticorpos anti-rotavírus em populações indígenas amazônicas ${ }^{7}$. Em um estudo envolvendo um total de 13 grupos, Linhares e col. ${ }^{7}(1986)$ evidenciaram uma prevalência média de $56,0 \%$, variando de $17,0 \%$ a $93,3 \%$.

No caso dos Suruí e Karitiána, a elevada prevalência de positividade para anticorpos anti-rotavírus indica que tais organismos devem desempenhar importante papel na epidemiologia das diarréias entre essas populações. Entre os Karitiána, a freqüência de episódios de diarréia é bastante elevada, da ordem de 3,9 episódios por ano, em 1981, e 2,4 em $1982^{4}$. Quanto aos Suruí, devido à inexistência de registros nas enfermarias, não se dispõem de dados relativos à incidência de diarréia. Contudo, como mencionado por Coimbra Jr. ${ }^{2}$ (1989), infecções diarréicas constituem a maioria dos atendimentos na enfermaria da FUNAI na área Suruí.

Ao contrário do observado por Linhares e col. ${ }^{7}$ (1986), entre alguns dos grupos estudados, tanto os indivíduos Suruí como os Karatiána das diversas faixas etárias tendem a apresentar relativamente elevadas prevalências de soropositividade para anticorpos anti-rotavírus. Uma explicação possível é que ambas populações estão continuadamente expostas ao microrganismo, provavelmente devido às condições sanitárias precárias nas aldeias, favorecendo também a transmissão de bactérias e parasitas intestinais 3,4,12. Ainda que as populações Suruí e Karatiána sejam de reduzido tamanho, é provável que as freqüentes idas e vindas dos índios às cidades próximas das aldeias possibilite a constante reintrodução de cepas de rotavírus nas aldeias.

A possibilidade de que infecções por rotavírus ocorram a partir do contato com reservatórios silvestres também merece ser considerada ${ }^{8}$. Também cabe admitir que tenha ocorrido entre os Suruí e Karatiána uma propagação explosiva

Tabela. Prevalência (casos positivos/total) de positividade para anticorpos anti-rotavírus entre os grupos indigenas Suruí e Karitiána

\begin{tabular}{lcccc}
\hline \multirow{2}{*}{ Faixa Etária } & \multicolumn{2}{c}{ Suruí } & \multicolumn{2}{c}{ Karitiána } \\
\cline { 2 - 5 } & ELISA & IF & ELISA & IF \\
\hline $0<x<10$ & $2 / 2(100 \%)$ & $1 / 2(50,0 \%)$ & $8 / 14(57,1 \%)$ & $6 / 13(46,2 \%)$ \\
$10 \leqslant x<20$ & $16 / 19(84,2 \%)$ & $4 / 8(50,0 \%)$ & $6 / 7(85,7 \%)$ & $4 / 7(57,1 \%)$ \\
$20 \leqslant x<30$ & $11 / 21(52,4 \%)$ & $3 / 6(50,0 \%)$ & $5 / 5(100 \%)$ & $5 / 5(100 \%)$ \\
$x \geqslant 30$ & $11 / 17(64,7 \%)$ & $2 / 6(33,3 \%)$ & $5 / 5(100 \%)$ & $2 / 5(40,0 \%)$ \\
Total & $40 / 59(67,8 \%)$ & $10 / 22(45,5 \%)$ & $24 / 31(77,4 \%)$ & $17 / 30(56,7 \%)$ \\
\hline
\end{tabular}

ELISA - Técnica Imunoenzimática

IF - Imunofluorescência indireta 
do enteropatógeno em questão - pelas possíveis recentes epidemias - já que os percentuais de soropositividade por faixa etária são relativamente elevados.

SANTOS, R.V. et al. [Epidemiological studies among Amerindians of Rondônia, Brazil. IV. Serological survey for rotavírus antibodies among the Surui and Karitiána] Rev. Saúde públ., S. Paulo 25: 230-2, 1991. The authors present the results of a sero-epidemiological survey for rotavirus antibodies conducted among the Suruí and Karitiána, two amerindian groups of Rondonia, Brazilian Amazonia. The results indicate high percentages of seropositivity for both groups $(67.8 \%$ among the Surui and $77.4 \%$ among the Karitiana using ELISA and $45.5 \%$ for the Surui and $56.7 \%$ for the Karitiána using indirect immunofluorescence). Chi square tests indicated no statistically significant association between group and seropositivity. The results are discussed in the light of other studies conducted among Brazilian amerindian groups.

Keywords: Rotaviruses. Indians, south american.

\section{Referências Bibliográficas}

1. CANDEIAS, J.A.N. Etiologia viral das gastroenterites humanas. In: Trabulsi, L.R. org. Microbiologia das infecções intestinais. Rio de Janeiro, Livraria Atheneu, 1981. p.113-25

2. COIMBRA JR., C.E.A. From shifting cultivation to coffee farming: the impact of change on the health and ecology of the Suruí indians in the Brazilian Amazon. Indiana University, 1989. [Thesis]
3. COIMBra JR., C.E.A. \& MELLO, D.A. Enteroparasitoses e Capillaria sp. entre o grupo Suruí, Parque Indígena Aripuanã, Rondônia. Mem. Inst. Oswaldo Cruz, 76: 299-302, 1981.

4. COIMBRA JR., C.E.A. et al. Estudos epidemiológicos entre grupos indígenas de Rondônia. II. Bactérias enteropatogênicas e gastroenterites entre os Suruí e Karitiána. Rev. Fundação SESP, 30: 111-120, 1985.

5. EVELAND, W.C. et al. Characteristics of Escherichia coli serotypes in the Yanomama, a primitive Indian tribe of South America. Infect. and Immun., 4: 753-6, 1971.

6. LINHARES, A.C. et al An outbreak of rotavirus diarrhoea among a non-immune South American Indian community. Amer. J. Epidemiol., 113:703-10, 1981.

7. LINHARES, A.C. et al. Prevalence of rotavirus antibody among isolated South American Indian communities. Amer. J. Epidem., 123:699-709, 1986.

8. LINHARES, A.C. et al. Rotavirus infection in wild marsupials (Didelphis marsupialis) of the Amazon region. Trans. roy. Soc. trop. Med. Hyg., 80:20-4, 1986.

9. LOUREIRO, E.C.B. \& LINS, Z.C. Observações sobre a incidência de enterobactérias patogênicas em índios da tribo Parakanã. Rev. Fundação SESP, 22:43-4, 1976.

10. NEEL, J.V. et al. Further studies of the Xavante Indians. VIII. Some observations on blood, urine and stool specimens. Amer. J. trop. Med. Hyg., 17:474-85, 1968.

11. PAN-AMERICAN HEALTH ORGANIZATION. Diarrhoeal diseases in Americas. Epidemiol. Bull., 1:1-4, 1980.

12. SANTOS, R.V. et al. Prevalência de parasitoses intestinais no grupo indígena Karitiána, Rondônia. Ciênc. Cult., 37 (Supl.): 68, 1985.

Recebido para publicação em 14/11/1990
Reapresentado em 2/1/1991
Aprovado para publicação em $8 / 1 / 1991$ 